\title{
PERAN PROFITABILITAS DALAM HUBUNGAN KEPEMILIKAN MANAJERIAL DENGAN NILAI PERUSAHAAN \\ (Studi pada Perusahaan Manufaktur yang Terdaftar Di Bursa Efek Indonesia Tahun 2013-2016).
}

\author{
Ni'matuz Zahro', Zamrud Mirah Delima' \\ Program Studi Akuntansi Fakultas Ekonomi dan Bisnis Universitas Muria Mudus \\ ${ }^{1}$ ㄲikmah12357@gmail.com
}

\begin{abstract}
ABSTRAK
Tujuan dari penelitian ini adalah untuk menguji besarnya peran profitabilitas dalam hubungan kepemilikan manajerial dengan nilai perusahaan pada perusahaan manufaktur yang terdaftar di Bursa Efek Indonesia tahun 2013-2016. Jumlah sampel yang digunakan dalam penelitian ini yaitu 31 perusahaan. Metode pengumpulan data dilakukan menggunakan analisis regresi linier berganda. Data penelitian ini telah memenuhi syarat uji asumsi klasik yang meliputi: uji normalitas, uji multikolinearitas, uji autokorelasi, dan uji heteroskedastisitas. Hasil penelitian menunjukkan bahwa (1) kepemilikan manajerial berpengaruh positif terhadap nilai perusahaan dan (2) profitabilitas mampu memoderasi hubungan kepemilikan manajerial terhadap nilai perusahaan.
\end{abstract}

Kata kunci: Nilai Perusahaan, Kepemilikan Manajerial, Pertumbuhan Perusahaan, Profitabilitas.

\begin{abstract}
The purpose of this study is to examine the magnitude of the role of profitability in the relationship of managerial ownership with the value of the company in manufacturing companies listed on the Indonesia Stock Exchange 2013-2016. The number of samples used in this study were 31 companies. Methods of data collection were done using multiple linear regression analysis. The data of this study have met the requirements of classical assumption test which include: normality test, multicollinearity test, autocorrelation test, and heteroscedasticity test. The result of the research shows that (1) managerial ownership positively affects firm value and (2) profitability able to moderate managerial ownership relationship to firm value.
\end{abstract}

Keywords: Corporate Value, managerial Ownership, Corporate Growth, Profitability. 


\section{PENDAHULUAN}

Sartono (2010:27) menyatakan bursa efek merupakan lembaga yang menyelenggarakan kegiatan perdagangan sekuritas (Pasal 1:4 UU No.8/1005). Bursa Efek Indonesia (BEI) merupakan pengganbungan dari Bursa Efek Jakarta dan Bursa Efek Surabaya. BEI memberikan informasi dan menyebarkan data serta perkembangan harga saham kepada publik. Jumlah perusahaan yang terdaftar di BEI semakin banyak, membuat para investor harus pandai dalam menentukan investasi. Investor harus pandai menganalisis data yang ada untuk membuat suatu keputusan yang tepat dalam berinvestasi. Ada beberapa sektor perusahaan yang terdaftar di BEI, paling banyak didominasi oleh industri manufaktur. Banyaknya perusahaan menimbulkan terjadinya persaingan yang ketat, sehingga setiap perusahaan harus bisa meminimalisir persaingan dan meningkatkan efisiensi dan efektivitas perusahaan untuk tetap bertahan dalam dunia bisnis. Tujuan dari setiap perusahaan tidak lain adalah untuk memaksimalkan nilai perusahaan.

Berjalannya suatu perusahaan dapat dipengaruhi oleh nilai perusahaan. Nilai tersebut dapat menarik minat investor untuk menanamkan dananya kepada perusahaan. Dimana investor menanamkan saham pada perusahaan yang dianggap sehat dengan tujuan untuk mendapat keuntungan. Dalam berinvestasi, investor sangat memperhatikan tingkat profitabilitas, hutang, aset, kinerja, dan nilai perusahaan.

Menurut Modigliani dan Miller, nilai perusahaan hanya ditentukan oleh kemampuan perusahaan dalam menghasilkan pendapatan (earning power) dan risiko bisnis (Sudana, 2011). Kemakmuran suatu perusahaan dapat dilihat pada peningkatan nilai perusahaan, karena pada harga saham yang tinggi dan selalu meningkat dapat membuat pasar percaya akan prospek perusahaan kedepannya. Hal itu kaitannya erat dengan kemakmuran pemegang saham, karena jika harga saham perusahaan semakin meningkat maka sama halnya nilai perusahaan akan baik dimata para investor. Tolok ukur yang biasa digunakan untuk mengukur nilai perusahaan adalah dengan membandingkan harga saham dengan nilai buku perlembar saham, sehingga pemegang saham dalam hal ini sangat diutamakan dalam perusahaan (Ardian, 2012).

Kepemilikan manajerial merupakan faktor yang dapat mempengaruhi perubahan nilai suatu perusahaan. Manajer sangat berperan penting dalam perusahaan dan berperan aktif dalam mengembangkan perusahaan. Dalam meningkatkan nilai perusahaan manajer harus membuat suatu kebijakan. Hal itu karena manajer sebagai bagian dari kepemilikan saham. 
Pihak yang terlibat dalam perusahaan tidak hanya manajer, tetapi ada pemilik perusahaan, direktur dan kreditor yang memiliki kepentingan berbeda-beda (Wiranata dan Nugrahanti, 2013).

Selain itu profitabilitas merupakan faktor yang dapat mempengaruhi nilai perusahaan. Menurut Sudana (2011:22) profitabilitas adalah pengukuran dimana untuk mengetahui seberapa kemampuan perusahaan dalam menghasilkan laba dengan sumber yang dimiliki perusahaan. Semakin tinggi tingkat profitabilitas yang dicapai perusahaan, maka semakin tinggi nilai perusahaan. Pada dasarnya profitabilitas dijadikan sebagai ukuran kinerja dari suatu perusahaan, dengan adanya laba yang dihasilkan naik atau turun pada setiap periodenya. Pada saat profit meningkat, perusahaan dikatakan berhasil dalam meningkatkan kinerja sehingga akan mendapat tanggapan positif dari para investor. Investor menanamkan dana pada perusahaan dengan maksud mendapatkan kembali dana serta keuntungan modalnya (Fau, 2015).

\section{TINJAUAN PUSTAKA}

\section{Teori Persinyalan (Signalling Theory)}

Teori sinyal menurut Modigliani-Miller (MM) menyatakan bahwa setiap investor maupun manajer memiliki informasi yang sama tentang prospek suatu perusahaan. Pengumuman penawaran saham biasanya dianggap sebagai suatu sinyal (signal) bahwa prospek perusahaan kurang cerah menurut penilaian manajemennya. Sinyal (signal) merupakan suatu tindakan yang diambil oleh manajemen suatu perusahaan memberikan petunjuk kepada investor tentang bagaimana manajemen menilai prospek perusahaan tersebut (Brigham dan Houston, 2011:186).

\section{Kerangka Berpikir}

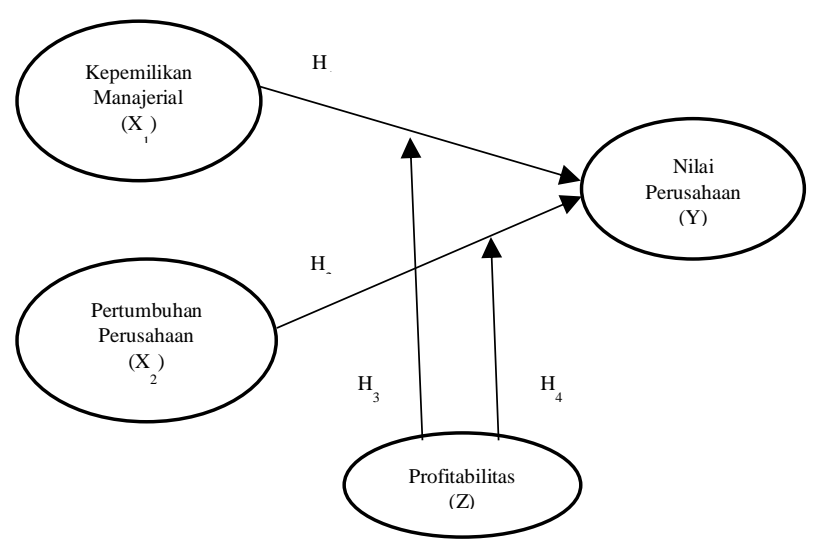




\section{Pengembangan Hipotesis}

\section{Pengaruh Kepemilikan Manajerial terhadap Nilai Perusahaan}

Kepemilikan manajerial merupakan saham yang dimiliki oleh pihak manajemen yang didapat dari usaha keras dalam mempertahankan kelangsungan suatu perusahaan. Sartono (2010) menyatakan bahwa hampir semua manajer keuangan setuju terhadap tujuan memaksimumkan kemakmuran pemilik perusahaan. Dengan tingginya tingkat kemakmuran pemegang saham maka nilai perusahaan juga akan meningkat.

Penelitian Suastini, dkk (2016) menunjukkan hasil penelitian bahwa kepemilikan manajerial berpengaruh negatif dan signifikan terhadap nilai perusahaan Hasil penelitian tersebut bertolak belakang dengan hasil penelitian Rahmatia dan Andayani (2015), dan Trisnabudi dan Fitria (2015) menyatakan bahwa kepemilikan manajerial berpengaruh positif terhadap nilai perusahaan. Sehingga dapat diajukan hipotesis sebagai berikut:

\section{$H_{1}$ : Kepemilikan manajerial berpengaruh positif terhadap nilai perusahaan.}

\section{Pengaruh Kepemilikan Manajerial terhadap Nilai Perusahaan yang Dimoderasi Profitabilitas}

Meningkatnya kepemilikan manajer akan mendorong manajer untuk bertindak secara bijak dalam mengambil keputusan, karena manajer sebagai pemilik akan ikut menanggung konsekuensi dari keputusannya. Konflik yang muncul antara pemilik dengan manajer yaitu akibat dari para manajer yang menggunakan uang kas perusahaan dengan tujuan untuk meningkatkan profitabilitas. Namun, pada pihak pemilik berharap uang kas dibagikan dalam bentuk cash dividen untuk mengurangi agency conflict. Ardian (2012) mengungkapkan bahwa seorang manajer akan bertindak sesuai keinginan pemilik dengan adanya kompensasi, kompensasi tersebut biasa berupa kompensasi minimum, kompensasi tambahan dan pemberian stock option. Hal itu diyakini dapat menurunkan konflik keagenan, karena semakin baik kinerja perusahaan terutama oleh manajer, maka semakin tinggi harga saham. Sehingga akan meningkatkan kemakmuran pemegang saham termasuk pada meningkatnya kepemilikan saham oleh manajer. Jadi semakin tinggi kepemilikan manajerial diikuti dengan profitabilitas yang tinggi, maka semakin tinggi nilai perusahaan.

Pada penelitian Ramadhani, dkk (2017) menyatakan bahwa profitabilitas dapat memoderasi hubungan kepemilikan manajerial terhadap nilai perusahaan dan pada penelitian 
Asmawati dan Amanah (2013) mengungkapkan bahwa profitabilitas mampu memoderasi hubungan antara struktur kepemilikan yang didalamnya terdapat faktor kepemilikan manajerial dan keputusan keuangan terhadap nilai perusahaan. Dengan demikian dapat disusun hipotesis sebagai berikut:

\section{$\mathrm{H}_{2}$ : Profitabilitas mampu memoderasi pengaruh kepemilikan manajerial terhadap} nilai perusahaan.

\section{METODE PENELITIAN}

\section{Populasi}

Populasi dalam penelitian ini adalah perusahaan manufaktur yang terdaftar di Bursa Efek Indonesia tahun 2013-2016.

\section{Sampel}

Pemilihan sampel menggunakan metode purposive sampling dengan tujuan untuk mendapatkan sampel sesuai kriteria yang ditentukan.

\section{Statistik Deskriptif}

Statistik deskriptif mempunyai tujuan untuk memberikan gambaran mengenai variabelvariabel penelitian mengenai nilai minimum, nilai maksimum, nilai rata-rata (mean), standar deviasi, dan jumlah sampel dari variabel penelitian.

\section{Uji Asumsi Klasik}

\section{Uji Normalitas Data}

Uji normalitas data bertujuan untuk menguji apakah dalam variabel dependen dan variabel independen memiliki data berdistribusi normal atau tidak, maka dapat menggunakan histrogram dan normal probability plot dari residual tersebut (Ghozali, 2016:154).

\section{Uji Multikolinearitas}

Tujuan dilakukan uji multikolinearitas adalah untuk menguji apakah dalam model regresi ditemukan adanya korelasi antar variabel independen. Model regresi dinyatakan bebas dari multikolinearitas jika mempunyai tolerance lebih dari 0,10 dan nilai VIF dibawah 10 (Ghozali, 2016:103).

\section{Uji Heteroskedastisitas}

Tujuan uji heteroskedastisitas adalah untuk mengetahui apakah dalam model regresi terjadi ketidaksamaan variance dari residual satu pengamatan ke pengamtan yang lain (Ghozali, 2016:134). Model regresi yang baik adalah tidak terjadi heteroskedastisitas. Pengujian heteroskedastisitas dalam penelitian ini menggunakan uji glejser. 


\section{Uji Autokorelasi}

Uji autokorelasi bertujuan menguji apakah dalam suatu model regresi linier ada korelasi antara kesalahan pengganggu pada periode $t$ dengan kesalahan penggangu pada periode $\mathrm{t}-1$ (Ghozali, 2016:134).

\section{Analisis Regresi Linier Berganda}

Analisis linier berganda digunakan untuk mendapatkan regresi yang akan menentukan apakah hipotesis yang dibuat akan diterima atau ditolak.

\section{Uji Hipotesis}

\section{Koefisien Determinasi $\left(\mathbf{R}^{2)}\right.$}

Analisis koefisien determinasi (Adjusted $\mathrm{R}^{2}$ ) digunakan untuk mengukur berapa persen pengaruh yang diberikan variabel independen terhadap variabel dependen. Nilai yang mendekati 1 berarti variansi independen memberikan hampir semua informasi yang dibutuhkan untuk memprediksi variasi variansi dependen (Ghozali, 2016:97).

\section{Uji Simultan (Uji F)}

Uji $\mathrm{F}$ disebut dengan analysis of variance (ANOVA) pengujian ini bertujuan untuk menguji apakah variabel independen berpengaruh bersama-sama terhadap variabel dependen (Ghozali, 2016:98).

\section{Uji Signifikansi Parameter Individual (Uji Statistik t)}

Uji t digunakan untuk menunjukkan seberapa besar pengaruh satu variabel independen secara sendiri-sendiri dalam menjelaskan variasi variabel dependen (Ghozali, 2016:99).

\section{HASIL DAN PEMBAHASAN}

\section{Statistik Deskriptif}

\section{Tabel 4.2}

\section{Hasil Analisis Statistik Diskriptif}

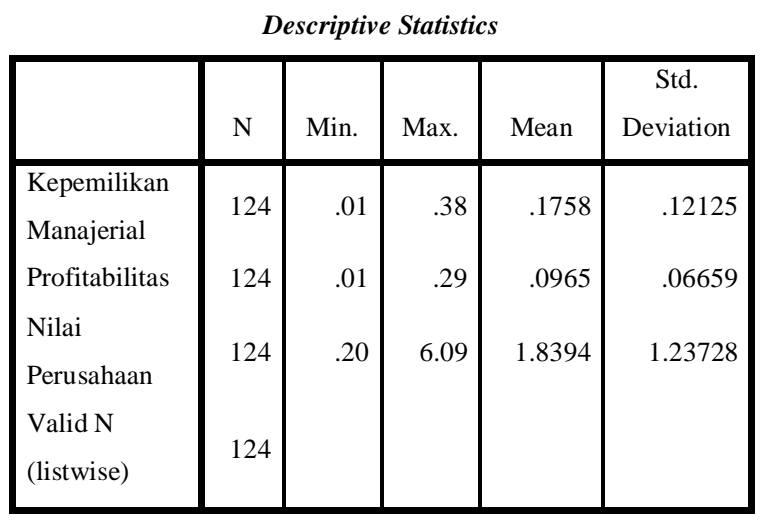


Sumber: data diolah, 2018

\section{Uji Normalitas}

Tabel 4.3

Hasil Uji Kolmogorov Smirnov

One-Sample Kolmogorov-Smirnov Test

\begin{tabular}{|ll|r|}
\hline & & $\begin{array}{r}\text { Unstandardi } \\
\text { zed Residual }\end{array}$ \\
\hline$N$ & & 124 \\
Normal Parameters $^{a, b}$ & Mean & .0000000 \\
& Std. & \\
& Deviation & .94696712 \\
Most Extreme & Absolute & .070 \\
Differences & Positive & .070 \\
& Negative & -.044 \\
Test Statistic & & .070 \\
Asymp. Sig. (2-tailed) & & $.200^{\mathrm{c}, \mathrm{d}}$ \\
\hline
\end{tabular}

Sumber: data diolah, 2018

Berdasarkan hasil pada tabel diatas, diketahui bahwa nilai signifikan dari kolmogorov-smirnov sebesar 0,200. Nilai ini lebih besar dari 0,05 sehingga data terdistribusi normal atau memenuhi asumsi klasik normalitas residual, dengan demikian asumsi normalitas terpenuhi

\section{Uji Multikolinearitas}

Tabel 4.4

\section{Hasil Uji Multikolinearitas}

\begin{tabular}{|l|c|c|}
\hline \multicolumn{1}{|c|}{ Variabel } & Tolerance & VIF \\
\hline $\begin{array}{l}\text { Kepemilikan } \\
\text { Manajerial }\end{array}$ & 0,414 & 2,416 \\
\hline $\begin{array}{l}\text { Interaksi } \\
\text { Kepemilikan } \\
\text { Manajerial dengan } \\
\text { Profitabilitas }\end{array}$ & 0,414 & 2,416 \\
\hline
\end{tabular}

Sumber: data diolah, 2018

Dari tabel diatas menunjukan bahwa semua variabel memiliki nilai tolerance lebih dari 0,10 dan memiliki nilai VIF kurang dari 10. Jadi dapat disimpulkan tidak terjadi multikolinearitas antar variabel bebas dalam model regresi. 


\section{Uji Heteroskedastisitas}

\section{Tabel 4.5}

\section{Hasil Uji Glejser}

Coefficients $^{a}$

\begin{tabular}{|c|c|c|c|c|c|c|}
\hline \multirow{2}{*}{\multicolumn{2}{|c|}{ Model }} & \multicolumn{2}{|c|}{ Unstandardized Coefficients } & $\begin{array}{l}\text { Standardized } \\
\text { Coefficients }\end{array}$ & \multirow[b]{2}{*}{$\mathrm{t}$} & \multirow[b]{2}{*}{ Sig. } \\
\hline & & B & Std. Error & Beta & & \\
\hline \multirow[t]{4}{*}{1} & (Constant) & .769 & .095 & & 8.129 & .000 \\
\hline & Keepemilika & 347 & 672 & 073 & 515 & 607 \\
\hline & Manajerial & & & & & \\
\hline & $\mathrm{X} 1 . \mathrm{Z}$ & 1.913 & 3.509 & .077 & .545 & .587 \\
\hline
\end{tabular}

Sumber: data diolah, 2018

Berdasarkan hasil uji heteroskedastisitas dengan menggunakan uji glejser pada tabel 4.5 diperoleh hasil bahwa kepemilikan manajerial dan interaksi kepemilikan manajerial dengan profitabilitas sudah bebas dari masalah heteroskedastisitas yang ditunjukan dengan tingkat signifikansi lebih dari 0,05. Dengan demikian asumsi heterokedastisitas terpenuhi.

\section{Uji Autokorelasi}

Tabel 4.6

\section{Hasil Uji Autokorelasi}

\begin{tabular}{|l|r|}
\hline \multicolumn{2}{|c|}{ Runs Test } \\
\hline & Unstandardized Residual \\
\hline Test Value ${ }^{a}$ & -13652 \\
Cases $<$ Test Value & 62 \\
Cases > = Test Value & 62 \\
Total Cases & 124 \\
Number of Runs & 71 \\
Z & 1.443 \\
Asymp. Sig. (2-tailed) & .149 \\
\hline
\end{tabular}

Sumber: data diolah, 2018

Berdasarkan tabel 4.6 mengenai hasil uji autokorelasi nampak bahwa nilai sig. $0,149>0,05$ berarti data tidak mengalami autokorelasi sehingga uji autokorelasi terpenuhi

\section{Analisis Regresi Linier Berganda}


[ACCOUNTING GLOBAL JOURNAL] E ISSN

\begin{tabular}{|c|c|c|c|c|c|c|}
\hline \multirow[b]{2}{*}{ Model } & & \multicolumn{2}{|c|}{$\begin{array}{l}\text { Unstandardized } \\
\text { Coefficients }\end{array}$} & \multirow{2}{*}{$\begin{array}{c}\text { Standardized } \\
\text { Coefficients }\end{array}$} & \multirow[b]{2}{*}{$\mathrm{t}$} & \multirow[b]{2}{*}{ Sig. } \\
\hline & & B & Std. Error & & & \\
\hline 1 & (Constant) & .925 & .155 & & 5.963 & .000 \\
\hline & KM & 2.636 & 1.104 & .258 & 2.389 & .018 \\
\hline & $\begin{array}{l}\text { KM dengan } \\
\text { Profitabilitas }\end{array}$ & 22.544 & 5.751 & .424 & 3.920 & .000 \\
\hline
\end{tabular}

Sumber: data diolah, 2018

Dari tabel diatas dapat dirumuskan suatu persamaan regresi untuk mengetahui pengaruh kepemilikan manajerial dan pertumbuhan perusahaan terhadap nilai perusahaan dengan profitabilitas sebagai variabel moderasi adalah sebagai berikut:

$\mathrm{Y}=0,925+2,636 \mathrm{X} 1+22,544 \mathrm{X} 1 . \mathrm{Z}+\mathrm{e}$

\section{Pengujian Hipotesis}

\section{Koefisien Determinasi $\left(\mathbf{R}^{2}\right)$}

Tabel 4.8

\section{Hasil Analisis Koefisien Determinasi $\left(\mathbf{R}^{2}\right)$}

\begin{tabular}{|l|c|r|r|r|}
\hline \multicolumn{1}{|c|}{ Model Summary } \\
Model & $\mathrm{R}$ & $\begin{array}{c}\text { R } \\
\text { Square }\end{array}$ & $\begin{array}{c}\text { Adjusted R } \\
\text { Square }\end{array}$ & $\begin{array}{l}\text { Std. Error of } \\
\text { the Estimate }\end{array}$ \\
\hline 1 & $.644^{\mathrm{a}}$ & .414 & .405 & .95476 \\
\hline
\end{tabular}

Sumber: data diolah, 2018

Nilai koefisien determinasi (adjusted $R$ Square) sebesar 0,405 menunjukkan bahwa kepemilikan manajerial dan interaksi kepemilikan manajerial dengan profitabilitas secara simultan memberikan pengaruh sebesar $40,5 \%$ terhadap nilai perusahaan pada perusahaan manufaktur yang terdaftar di Busa Efek Indonesia periode 2013-2016, sedangkan sisanya 59,5\% merupakan pengaruh faktor-faktor lain di luar variabel penelitian.

\section{Uji F}

\section{Tabel 4.9}

\section{Hasil Analisis Uji F}

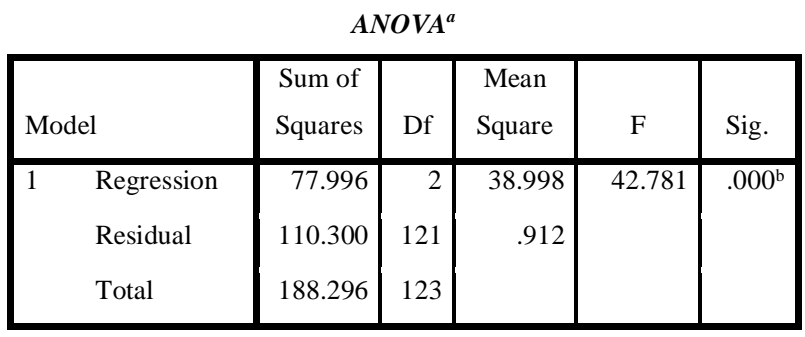

Sumber: data diolah, 2018 
Tabel tersebut menunjukkan bahwa kepemilikan manajerial dan interaksi kepemilikan manajerial dengan profitabilitas secara bersama-sama terhadap nilai perusahaan. Hal tersebut dibuktikan dengan tingkat signifikan 0,000 yang lebih kecil dari $\alpha(0,05)$.

Uji t

Tabel 4.10

\section{Hasil Analisis Uji t}

\begin{tabular}{|l|c|c|}
\hline \multicolumn{1}{|c|}{ Variabel } & $t$ & Sig. \\
\hline $\begin{array}{l}\text { Kepemilikan } \\
\text { Manajerial }\end{array}$ & 2,389 & 0,018 \\
\hline $\begin{array}{l}\text { Interaksi } \\
\text { Kepemilikan } \\
\text { Manajerial dengan } \\
\text { Profitabilitas }\end{array}$ & 3,920 & 0,000 \\
\hline
\end{tabular}

Sumber: data diolah, 2018

\section{Pembahasan}

\section{Pengaruh Kepemilikan Manajerial terhadap Nilai Perusahaan}

Berdasarkan hasil pengujian hipotesis pertama $\left(\mathrm{H}_{1}\right)$ diperoleh nilai signifikansi 0,018 $<\alpha 0,05$ yang menunjukkan kepemilikan manajerial berpengaruh positif terhadap nilai perusahaan. Dalam hal ini perusahaan yang mempunyai kepemilikan manajerial yang tinggi dapat meningkatkan nilai sebuah perusahaan.

\section{Profitabilitas Memoderasi Pengaruh Kepemilikan Manajerial terhadap Nilai Perusahaan}

Berdasarkan hasil pengujian hipotesis ketiga $\left(\mathrm{H}_{2}\right)$ diperoleh nilai signifikansi $0,000<$ a 0,05 yang menunjukkan bahwa profitabilitas memoderasi hubungan kepemilikan manajerial terhadap nilai perusahaan. Dalam hal ini perusahaan yang memiliki kepemilikan manajerial yang tinggi didukung dengan profitabilitas yang tinggi dapat meningkatkan nilai perusahaan.

\section{KESIMPULAN}

Berdasarkan hasil pengujian hipotesis pertama $\left(\mathrm{H}_{1}\right)$ menunjukkan bahwa kepemilikan manajerial berpengaruh positif terhadap nilai perusahaan. Dalam hal ini perusahaan yang mempunyai kepemilikan manajerial yang tinggi dapat meningkatkan nilai sebuah 
perusahaan. Hasil pengujian hipotesis kedua $\left(\mathrm{H}_{2}\right)$ menunjukkan bahwa profitabilitas memoderasi hubungan kepemilikan manajerial terhadap nilai perusahaan. Dalam hal ini perusahaan yang memiliki kepemilikan manajerial yang tinggi didukung dengan profitabilitas yang tinggi dapat meningkatkan nilai perusahaan.

\section{Keterbatasan}

Setelah analisis tersebut, penelitian ini memiliki beberapa keterbatsan, yaitu (1) variabel independen pengaruh kepemilikan manajerial dan interaksi kepemilikan manajerial dengan profitabilitas hanya mampu menjelaskan $40,5 \%$ variasi besarnya nilai perusahaan, sedangkan sisanya 59,5\% dijelaskan oleh variabel lain, sehingga diperlukan variabel lain yang kemungkinan dapat berpengaruh terhadap nilai perusahaan. Fokus penelitian ini hanya pada perusahaan manufaktur yang terdaftar di Bursa Efek Indonesia periode 2013-2016 sehingga tidak dapat menggambarkan hasil data secara jelas berkaitan dengannilai perusahaan.

\section{Saran}

Bagi manajemen perusahaan sebaiknya dapat mempertahankan serta meningkatkan tingkat laba pada perusahaan sehingga akan selalu meningkatkan nilai perusahaan dan faktor yang dapat mempengaruhi nilai perusahaan seperti kepemilikan manajerial dan profitabilitas. Diharapkan penelitian selanjutnya, menambah variabel yang terkait dengan peningkatan nilai perusahaan, seperti corporate social responsibility seperti pada penelitian yang dilakukan oleh Ramadhani (2017). Diharapkan penelitian selanjutnya memperpanjang periode penelitian dan memperluas obyek penelitian berkaitan dengan perusahaan-perusahaan yang memiliki peningkatan nilai perusahaan.

\section{DAFTAR PUSTAKA}

Ardian, Jun. 2012. Pengaruh Struktur Modal, Pertumbuhan Perusahaan, Capital Expenditure, dan Insentif manajer terhadap Nilai Perusahaan dengan Profitabilitas sebagai Variabel Intervening. Jurnal Bisnis Strategi. Vol.21, No. 2, Desember.

Asmawati dan Lailatul Amanah. 2013. Pengaruh Struktur Kepemilikan, Keputusan Keuangan terhadap Nilai Perusahaan: Profitabilitas sebagai Variabel Moderating. Jurnal Ilmu \& Riset Akuntansi. Vol. 2 No. 4.

Brigham, F. Eugene and Joel F. Houston. 2011. Dasar-dasar Manajemen Keuangan. Jakarta: Salemba Empat.

Fau, Nia Rositawati. 2015. Pengaruh Struktur Modal, Pertumbuhan Perusahaan, Ukuran Perusahaan dan Profitabilitas terhadap Nilai Perusahaan pada Perusahaan Manufaktur yang terdaftar di Bursa Efek Indonesia. Skripsi. Universitas Negeri Yogyakarta. 
Ghozali, Imam. 2016. Aplikasi Analisis Multivariete dengan Program IBM SPSS 23. Semarang: Universitas Diponegoro.

Rahmatia, Tri Lasita dan Andayani. 2015. Pengaruh Kepemilikan Manajerial terhadap Nilai Perusahaan: Tanggung Jawab Sosial sebagai Variabel Moderating. Jurnal Ilmu dan Riset Akuntansi. Surabaya. Vol. 4, No. 3.

Ramadhani, Ajeng Ricky, I Gusti Ayu Purnamawati, dan Edy Sujana. 2017. Pengaruh Corporate Responsibility dan Kepemilikan Manajerial terhadap Nilai Perusahaan dengan Profitabilitas sebagai Variabel Moderasi. E-journal S1 Ak. Universitas Pendidikan Ganesha. Vol. 7, No. 1 Tahun 2017.

Sartono, Agus. 2010. Manajemen Keuangan: Teori dan Aplikasi. Yogyakarta: BPFE.

Suastini, Ida Bagus Anom Purbawangsa, dan Henny Rahyuda. 2016. Pengaruh Kepemilikan Manajerial dan Pertumbuhan Perusahaan terhadap Nilai Perusahaan Manufaktur di Bursa Efek Indonesia (Struktur Modal sebagai Variabel Moderasi). E-Jurnal Ekonomi dan Bisnis. Universitas Udayana 5.1, hal. 143-172.

Sudana. 2011. Manajemen Keuangan Perusahaan: Teori dan Praktik. Jakarta: Erlangga.

Trisnabudi, Ardian Noor dan Astri Fitria. 2015. Struktur Kepemilikan, Kebijakan Dividen terhadap Nilai Perusahaan dengan Kebijakan Hutang. Jurnal Ilmu dan Riset Akuntansi. Vol. 4, No. 6, hal. 1-23.

Wiranata, Yulius Ardy dan Yeterina Widi Nugrahanti. 2013. Pengaruh Struktur Kepemilikan terhadap Profitabilitas Perusahaan Manufaktur di Indonesia. Jurnal Akuntansi dan Keuangan. Universitas Kristen Satya Wacana. Vol. 15, No. 1, hal. 15-26. 